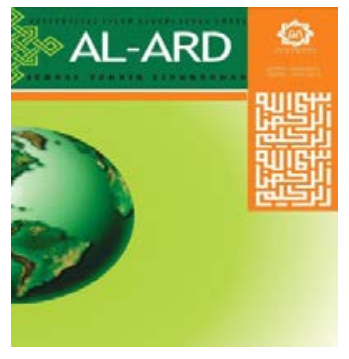

Al-Ard: Jurnal Teknik Lingkungan

Vol.5 No.1 - September 2019 (hal. 45-53)

http://jurnalsaintek.uinsby.ac.id/index.php/alard/index
Al-Ard:

Jurnal

Teknik Lingkungan

\title{
Analisis Kualitas Air Sungai Bawah Tanah Gua Ngerong, Kecamatan Rengel, Tuban \\ Dedy Suprayogi ${ }^{1}$, Sulistiya Nengse ${ }^{2}$, Abdul Hakim ${ }^{3}$ \\ 1,2,3 Universitas Islam Negeri Sunan Ampel Surabaya, Indonesia \\ dsuprayogi@uinsby.ac.id \\ sulistiya@uinsby.ac.id \\ Abdul.hakim@uinsby.ac.id
}

\begin{abstract}
Fulfillment of water quality requirements is absolutely necessary to fulfill primary human needs, especially drinking water and clean water sources, both in quantity and quality. Study of the underground caverns found the fact that in terms of quantity of water availability in the reservoir is able to meet the needs of residents of the Rengel District, but qualitatively not yet known the water quality in the reservoir. The purpose of this study was to measure the water quality of underground caves in caves which include temperature, turbidity, TDS, DO and $\mathrm{pH}$. The method used in this study is a qualitative method to measure the value of water quality. The research sample was taken with three repetitions for data validity. The sampling location is the underground cave system with a length of $1 \mathrm{~km}$, sample points include dark zone 1, dark zone 2 , dark zone 3, and dim zone. Measurements were taken in the laboratory. The results of the study showed that the average values for temperature, turbidity, TDS, DO and pH were $26.7 ; 1,9 ; 348.2 ; 1,6$; and 7.1 . The conclusion obtained from this study is that all indicators except DOs meet environmental quality standards set by the government.
\end{abstract}

Keywords: water quality, Ngerong caves, rivers, karst Tuban.

\begin{abstract}
Abstrak
Pemenuhan syarat kualitas air mutlak diperlukan untuk pemenuhan kebutuhan primer manusia, khususnya sumber air minum dan air bersih baik secara kuantitas maupun kualitas. Penelusuran terhadap sungai bawah tanah goa ngerong menemukan fakta bahwa secara kuantitas ketersediaan air pada reservoir tersebut mampu memenuhi kebutuhan penduduk wilayah Kecamatan Rengel, namun secara kualitatif belum diketahui kualitas air pada reservoir yang terletak pada daerah karst tuban tersebut. Tujuan dari penelitian ini adalah untuk mengukur kualitas air sungai bawah tanah goa ngerong yang meliputi suhu, kekeruhan, TDS, DO dan $\mathrm{pH}$. Metode yang digunakan dalam penelitian ini adalah metode kualitatif untuk mengukur nilai kualitas air. Sampel penelitian diambil dengan tiga kali pengulangan untuk validitas data. Lokasi pengambilan sampel adalah system sungai bawah tanah goa ngerong dengan panjang $1 \mathrm{~km}$, titik sampel antara lain adalah zona gelap 1, zona gelap 2, zona gelap 3, dan zona remang. Pengukuran dilakukan pada laboratorium lapangan dan labkes Kota Surabaya. Hasil dari penelitian menunjukkan bahwa nilai rata-rata untuk suhu, kekeruhan, TDS, DO dan pH adalah 26,7; 1,9; 348,2; 1,6; dan 7,1. Kesimpulan yang di dapat dari penelitian ini adalah bahwa semua indikator kecuali DO memenuhi baku mutu lingkungan yang ditetapkan oleh pemerintah.

Kata kunci: kualitas air, Goa Ngerong, sungai bawah tanah, kars Tuban.
\end{abstract}

\section{PENDAHULUAN}

Tingginya tingkat pencemaran air dan peningkatan jumlah penduduk berdampak terhadap naiknya kebutuhan air bersih dan air minum baik secara lokal maupun global. Di Indonesia menurut kelompok kerja air minum dan penyehatan lingkungan, pada tahun 2015, pemenuhan air minum secara nasional kurang dari 70\% (ampl.or.id, 2018). Hal ini merupakan kabar yang kurang menggembirakan dimana target Millennium Development Goals (MDGs) yang berakhir pada tahun tersebut tidak tercapai. Kemudian, dengan mengadopsi Sustainable Development Goal (SDGs) pemerintah mencanangkan pencapaian akses air minum $100 \%$ penduduk pada akhir tahun 2019. 
Pemenuhan kebutuhan air bersih saat ini tidak hanya terpaku pada jumlah namun juga pada kualitas air yang akan digunakan. Pada tahun 2016, indeks kualitas air Indonesia sebesar 60,38, akan tetapi pada tahun 2017 turun menjadi 58,68 (Kementrian Lingkungan Hidup dan Kehutanan Republik Indonesia, 2018). Hal ini menunjukkan adanya penurunan kualitas air di Indonesia.

Kondisi geografis Indonesia, terutama pulau Jawa sangat unik. Pulau ini memiliki banyak sekali jenis tanah dari humus, pasir, hingga pegunungan kapur berongga. Keberadaan pegunungan kapur, atau biasa diistilahkan dengan kawasan karst menyebar baik dipesir selatan maupun pesisir utara pulau jawa. Pada sisi selatan, terkenal dengan kawasan karst gunung kidul di Yogyakarta hingga pacitan kearah timurdan terus berlanjut hingga pesisir banyuwangi di ujung timur. Sedangkan pada sisi utara, kawasan karst membentang dari daerah gresik hingga tuban. Salah satu wilayah karst yang produktif dalam menghasilkan air adalah karst rengel dengan aliran sungai bawah tanahnya yaitu sistem sungai bawah tanah goa ngerong. Goa Ngerong memiliki sungai bawah tanah yang muncul menjadi sungai permukaan dan bermuara di Bengawan Solo.

Senada dengan IUCN terkait dengan peranan penting kawasan karst bagi keanekaragaman dan biodiversitas serta kekayaan khasanah alam, diperlukan usaha bersama untuk menjaga kekayaan dan keunikan kawasan karst baik di permukaan maupun di bawah permukaan, eksokarst dan endokarst. Selama ini masyarakat memandang kawasan karst hanya sebagai kawasan tandus dan kritis yang tidak memliki potensi. Anggapan ini memicu munculnya paradigma bahwa memanfaatkan kawasan karst hanya dapat dilakukan dengan menambangnya saja. Pemahaman yang demikian berdampak sangat fatal dalam jangka panjang, karena kawasan karst menyimpan potensi sumber air yang melimpah di bawah tanah. Air di simpan batuan gamping di kawasan karst melalui rekahan-rekahan mikro dan akan diakumulasikan di lorong-lorong yang lebih besar dan akan dikeluarkan dalam bentuk mata air melalui mulut-mulut Goa. Keutuhan batuan sebagai penyerap air dan terjaganya kondisi ekosistem Goa yang memiliki sungai bawah tanah akan menjaga ketersediaan dan kualitas sumber air di kawasan karst.
Goa Ngerong merupakan Goa terpanjang di Kawasan Karst Tuban yang terletak di Desa Rengel, Kecamatan Rengel dengan panjang mencapai 1800 m (Prakarsa dan Ahmadidn, 2013). Goa Ngerong memiliki sungai bawah tanah yang muncul menjadi sungai permukaan dan bermuara di Bengawan Solo dengan debit air sekitar 573,7 liter/detik (Rahmadi, 2002). Dengan debit sebesar itu, sungai bawah tanah Goa Ngerong mampu menyuplai kebutuhan air hampir 500.000 orang penduduk sekitar.

Menurut Wardhana, dkk (2013), persyaratan utama yang harus dipenuhi oleh sumber air bersih antara lain: kualitas, kuantitas, kontinyuitas, mudah diperoleh konsumen, dan harga air relative murah. Dengan debit sebesar 573,7 liter/detik (Rahmadi, 2002), sungai bawah tanah Gua Ngerong mampu menyuplai kebutuhan air hampir 500.000 orang penduduk sekitar. Pada musim penghujan, kedalaman air sungai bawah tanah Gua Ngerong lebih dari 3 meter, sedangkan pada musim kemarau sebesar 0,5 hingga 3 meter (Priyowinata, 2010). Hal ini menunjukkan adanya kontinyuitas ketersediaan air di Gua Ngerong meskipun pada musim kemarau. Kondisi muara sungai bawah tanah Gua Ngerong yang muncul ke permukaan pun memudahkan masyarakat jika ingin mengambil atau memanfaatkan air tersebut.

Persyaratan air bersih yang belum diperhatikan dari sungai bawah tanah Gua Ngerong adalah dari segi kualias. Menurut Peraturan Menteri Kesehatan No. 416 Tahun 1990, kualitas air harus memenuhi syarat kesehatan yang meliputi persyaratan mikrobiologi, fisika, kimia, dan radioaktif. Menurut Said (1999), penyediaan air bersih yang berkualitas memegang peranan penting dalam peningkatan kesehatan lingkungan dan masyarakat. Adanya suplai air bersih yang sehat berkualitas dapat menurukan angka penderita penyakit, khususnya yang berhubungan dngan air (waternome deseases).

Dengan debit yang melimpah, kontinyuitas yang mencukupi, dan kemudahan dalam mengakses air maka air sungai bawah tanah Gua Ngerong dapat dijadikan alternatif sumber air bersih bagi masyarakat sekitar. Akan tetapi, masih perlu dilakukan penelitian terhadap kualitas air sungai bawah tanah Gua Ngerong agar air baku tersebut bisa dikatakan 
layak atau tidak digunakan sebagai sumber air bersih.

Berdasarkan latar belakang tersebut, penelitian ini akan menganalisis kualitas air sungai bawah tanah Gua Ngerong. Parameter kualitas air yang diukur adalah kualitas fisik yang terdiri atas suhu, Total Dissolved Solid (TDS), kekeruhan, sedangkan kualitas kimia diukur adalah $\mathrm{pH}$ dan dissolved oxygen (DO). Dengan adanya penelitian mengenai kualitas air sungai bawah tanah Gua Ngerong ini, diharapkan ada rekomendasi, baik untuk masyarakat maupun pemerintah mengenai kelayakan air sungai bawah tanah Gua Ngerong sebagai sumber air bersih.

\section{METODE PENELITIAN}

\section{Desain Penelitian}

Penelitian ini merupakan penelitian eksperimental kualitatif dimana sampel diambil secara langsung di sungai bawah tanah goa ngerong.

\section{Tempat dan Waktu Pelaksanaaan}

Penelitian dilakukan di Gua Ngerong kawasan karst Tuban dan laboratorium kesehatan daerah Kota Surabaya di jl. Gayungsari Barat. Waktu penelitian selama 3 bulan terhitung Juni 2019 hingga Agustus 2019.

\section{Variabel Penelitian}

Variabel dalam penelitian ini adalah parameter fisik dan kimia kualitas air. Parameter fisik dan kimia meliputi suhu, $\mathrm{pH}$, kekeruhan, total dissolved solid (TDS), dan Dissolved Oxygen (DO).

Data dalam penelitian ini merupakan data primer yang diperoleh dari studi secara langsung analisis parameter fisik dan kimia kualitas air di Sistem Sungai Bawah Tanah Gua Ngerong Kawasan Karst Tuban.

\section{Alat dan Bahan}

Alat dan bahan yang digunakan dalam penelitian ini antara lain:

1. Strorage box 72 liter

2. Headlamp

3. Sepatu boot

4. Helm caving

5. Perahu karet

6. Thermometer

7. DO meter

8. pH meter air
9. Camera under water

10. Botol sampel $600 \mathrm{ml}$

\section{Sampel penelitian}

Pengambilan sampel dilakukan pada malam hari karena goa ngerong memiliki keakayaan diversitas kelelawar yang sangat tinggi dibandingkan dengan goa lain di Jawa Timur, sehingga waktu yang tepat untuk pengambilan sampel adalah pada malam hari ketika kelelawar keluar sarang. Pengukuran suhu dilakukan secara langsung pada titik pengambilan sampel, sedangkan kekeruhan dilakukan analisis di laboratorium.

Untuk pengukuran sampel pH, DO, dan TDS dilakukan secara langsung di luar goa. Hal ini dikarenakan goa ngerong memiliki karakter gua basah sehingga sangat beresiko jika membawa peralatan elektronik yang nonwater resistant masuk ke dalam goa. Alat yang digunakan untuk analisis di lapangan yaitu thermometer, $\mathrm{pH}$ meter, DO meter, dan TDS meter. Sedangkan untuk kekeruhan di analisis dengan metode turbidimetri menggunakan turbidimeter.

Pengambilan sampel dilakukan sebanyak tiga kali pada empat titik yang berbeda yaitu zona gelap 1, 2, 3, dan zona remang. Zona gelap terletak didalam sungai bawah tanah yang tidak mendapatkan cahaya dari luar sama sekali, sedangkan zona remang terletak di dekat mulut gua. Untuk lebih jelasnya dapat dilihat pada Tabel 1 .

\begin{tabular}{ccl}
\multicolumn{3}{c}{ Tabel 1. Lokasi titik sampling } \\
\hline No. & Nama titik sampel & Keterangan \\
\hline 1. & G1 & Zona gelap 1 \\
\hline 2. & G2 & Zona gelap 2 \\
\hline 3. & G3 & Zona gelap 3 \\
\hline 4. & G4 & Zona remang \\
\hline
\end{tabular}

(Sumber: Hasil Analisis, 2019)

Pemilihan titik pengambilan sampel didasarkan pada pembagian empat titik sesuai panjang sungai secara proporsional. Pengambilan titik zona 3 tidak dilakukan pada hulu karena kondisi permukaan sedang tinggi, dimana mulut air terjun di dalam goa tidak dapat dilalui. Zona remang diambil tepat di mulut goa bagian dalam karena titik ini mendapat sedikit cahaya tidak langsung pada saat siang hari. Sedangkan zona 1 dan 2 merupakan perpotongan panjang sungai dari kedua titik sebelumnya. Titik pengambilan sampel ditampilkan pada Gambar 1. 


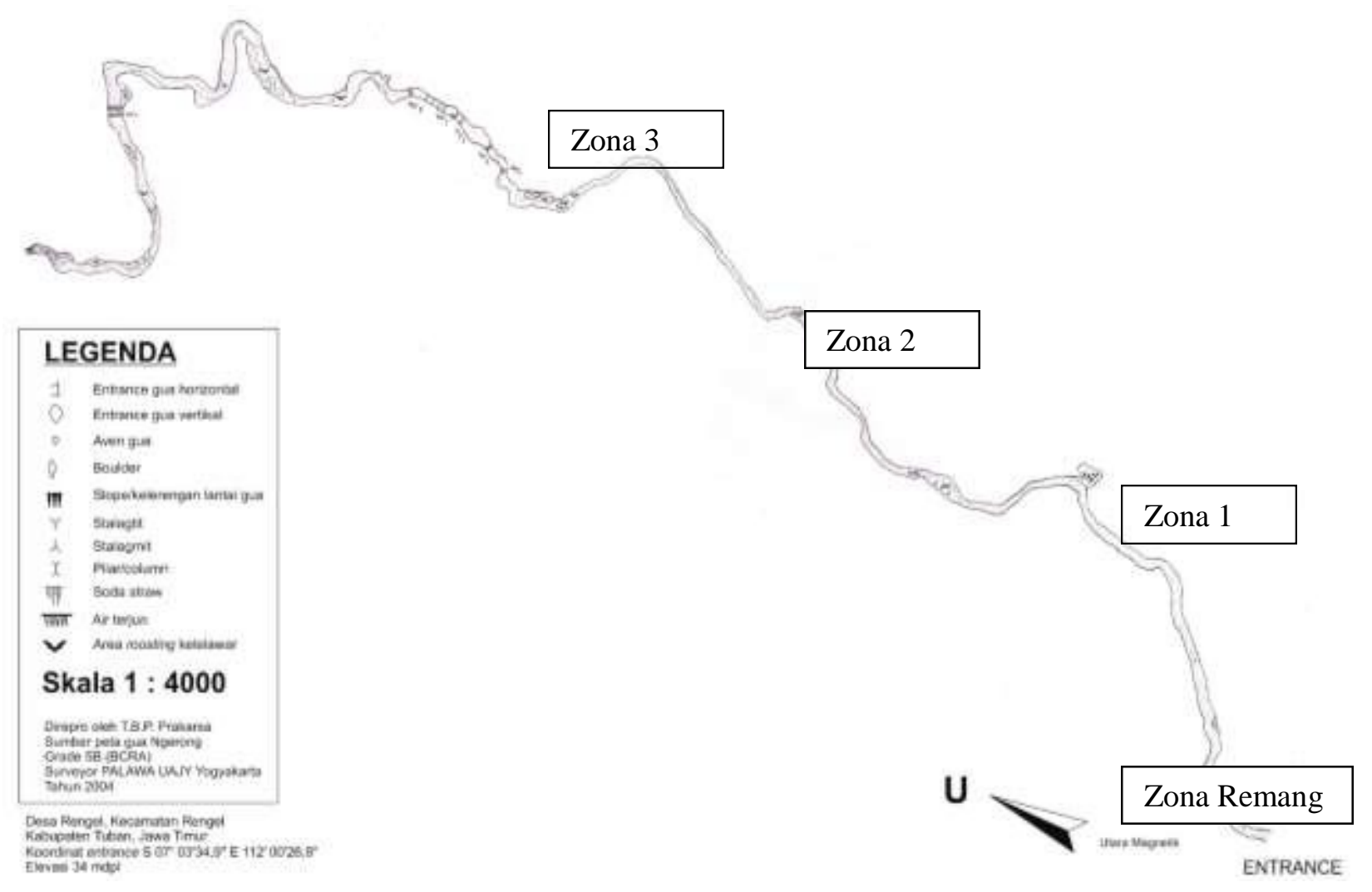

Gambar 1. Peta aliran sungai bawah tanah Goa Ngerong

(Sumber: Prakarsa, 2013)

\section{HASIL DAN PEMBAHASAN}

\section{Parameter Fisik}

\section{Suhu}

Parameter fisik pertama yang diukur adalah suhu menggunakan thermometer. Pengukuran dilakukan langsung di lapangan dengan hasil pengukuran disajikan pada Tabel 2.

Tabel 2. Suhu Air Bawah Tanah Gua Ngerong

\begin{tabular}{lcccc}
\hline \multirow{2}{*}{ No. sampel } & \multicolumn{4}{c}{ Suhu $\left({ }^{\mathbf{0}} \mathbf{C}\right)$} \\
\cline { 2 - 5 } & G1 & G2 & G3 & G4 \\
\hline Sampel 1 & 27,5 & 26,7 & 26,7 & 26,5 \\
\hline Sampel 2 & 26,6 & 26,4 & 26,6 & 26,6 \\
\hline Sampel 3 & 27,1 & 26,5 & 26,5 & 26,5 \\
\hline Rata-rata & 27,1 & 26,5 & 26,6 & 26,5 \\
\hline
\end{tabular}

(Sumber: Hasil Analisis, 2019)

Berdasarkan tabel di atas dapat diketahui bahwa rata-rata nilai suhu air sungai goa ngerong pada masing-masing titik (Zona 1, Zona 2, Zona 3, dan zona remang) adalah $27,1{ }^{\circ} \mathrm{C} ; 26,5{ }^{\circ} \mathrm{C} ; 26,6{ }^{\circ} \mathrm{C}$; dan $26,6^{\circ} \mathrm{C}$. Nilai tersebut telah memenuhi baku mutu air minum $25^{\circ} \mathrm{C} \pm 3^{\circ} \mathrm{C}$.

Temperatur atau suhu air akan mempengaruhi penerimaan masyarakat akan air tersebut dan dapat mempengaruhi reaksi kimia dalam pengolahanya terutama bila temperatur sangat tinggi. Suhu yang diinginkan adalah $\pm 3^{\circ} \mathrm{C}$ suhu udara di sekitarnya yang dapat memberikan rasa segar, tetapi iklim setempat atau jenis dari sumber air akan mempengaruhi temperatur air. Disamping itu suhu pada air mempengaruhi secara langsung toksisitas banyaknya bahan kimia pencemar, pertumbuhan mikroorganisme, dan virus (Suryani, 2013).

Faktor penting yang mempengaruhi tingkat kelimpahan plankton adalah suhu. Suhu air adalah faktor fisika yang sangat penting dalam kehidupan plankton. Suhu air dapat mempengaruhi kecepatan fotosintesis plankton pada badan air. Kecepatan fotosintesis sebanding dengan suhu air pada 
tingkatan tertentu hingga mencapai titik jenuh.

Dengan menggunakan data trend kawasan karst di Jura, Swiss, (Jeannin, 2016) menemukan bahwa setidaknya telah terjadi kenaikan suhu sekitar $0,5^{\circ} \mathrm{C}$ dalam 25 tahun terakhir. Data dan analisisnya menunjukkan bahwa pemecahan karbonat meningkat dengan cepat seiring dengan pemanasan global. Dengan menggunakan perhitungan tersebut, dengan mengabaikan faktor pengganggu, maka rata-rata suhu air sungai bawah tanah Goa Ngerong akan naik menjadi 27-27,5 ${ }^{\circ} \mathrm{C}$ dalam waktu 25 tahun ke depan.

Perbedaan suhu dapat terjadi karena perbedaan lokasi antar titik pengambilan sampel, arah aliran air, waktu pengukuran, dan pengaruh musim. Suhu air dapat mempengaruhi kelimpahan jumlah plankton, dimana pada umumnya plankton dapat hidup pada kisaran suhu $20-30^{\circ} \mathrm{C}$, dengan suhu yang optimal bagi pertumbuhan plankton adalah $29-31^{\circ} \mathrm{C}$.

\section{Kekeruhan}

Parameter fisik yang diukur selanjutnya adalah tingkat kekeruhan, yang dapat dilihat pada Tabel 3.

Tabel 3. Tingkat kekeruhan air bawah tanah Gua Ngerong

\begin{tabular}{ccccc}
\hline \multirow{2}{*}{$\begin{array}{c}\text { No } \\
\text { sampel }\end{array}$} & \multicolumn{4}{c}{ Tingkat kekeruhan (NTU) } \\
\cline { 2 - 5 } & G1 & G2 & G3 & G4 \\
\hline Sampel 1 & 1,50 & 1,44 & 1,69 & 0,91 \\
\hline Sampel 2 & 4,39 & 1,33 & 0,78 & 1,64 \\
\hline Sampel 3 & 3,91 & 2,32 & 1,03 & 1,59 \\
\hline Rata-rata & 3,27 & 1,69 & 1,17 & 1,38 \\
\hline
\end{tabular}

(Sumber: Hasil Analisis, 2019)

Berdasarkan tabel di atas dapat dilihat bahwa nilai rata-rata tingkat kekeruhan pada masing-masing titik adalah 3,27 NTU; 1,69 NTU; 1,17 NTU; dan 1,38 NTU. Nilai tersebut masih berada di bawah baku mutu air minum yaitu 25 NTU.

Turbiditas atau kekeruhan di dalam air disebabkan oleh adanya zat yang tersuspensi seperti lumpur, plankton, zat organik dan zat halus lainya. Turbiditas tidak memiliki hubungan langsung dengan zat padat tersuspensi, karena turbiditas tergantung dari ukuran dan bentuk butir partikel, sedangkan zat padat tersuspensi tergantung dengan zat yang tersuspensi tersebut.
Kekeruhan air sungai bawah tanah Gua Ngerong masih di bawah baku mutu semua karena air tanah memang cenderung memiliki kekeruhan yang rendah. Hal ini karena air limbah tidak secara langsung mengkontaminasi ke dalam air tanah. Air hujan atau air limbah yang terinfiltrasi ke dalam tanah otomatis akan terfiltrasi secara alamiah oleh butiran tanah. Sehingga air yang meresap ke dalam tanah kualitasnya lebih sedikit.

Dalam penelitiannya di sungai bawah tanah akuifer bawah tanah lembah Seine, Prancis, Massei menyatakan bahwa kekeruhan menjadi kontaminan utama dalam air bersih. Pada akuifer sistem sungai karst sendiri, kekeruhan dapat dipengaruhi oleh curah hujan, ketinggian air, dan konduktansi spesifik. Curah hujan dan ketinggian air dapat mempengaruhi kekeruhan badan air dalam waktu yang relatif singkat, sedangkan konduktansi spesifik dapat memeprngatruhi kekeruhan air dalam jangka waktu yang lebih lama (Massei, 2006).

\section{Total Dissolved Solid (TDS)}

Untuk parameter fisik selanjutnya adalah Total Dissolved Solid (TDS), dilakukan pengakuran di luar goa dengan menggunakan TDS meter, yang dapat dilihat pada Tabel 4 .

Tabel 4. Nilai TDS air sungai bawah tanah gua ngerong

\begin{tabular}{|c|c|c|c|c|}
\hline \multirow{2}{*}{$\begin{array}{c}\text { No } \\
\text { sampel }\end{array}$} & \multicolumn{4}{|c|}{ Nilai TDS (mg/L) } \\
\hline & G1 & G2 & G3 & G4 \\
\hline Sampel 1 & 339 & 349 & 349 & 350 \\
\hline Sampel 2 & 350 & 350 & 348 & 351 \\
\hline Sampel 3 & 348 & 345 & 350 & 349 \\
\hline Rata-rata & 345,7 & 348 & 349 & 350 \\
\hline
\end{tabular}

Berdasarkan tabel di atas dapat dilihat bahwa nilai rata-rata TDS di masing-masing titik pengambilan sampel adalah $345,7 \mathrm{mg} / \mathrm{L}$; $348 \mathrm{mg} / \mathrm{L} ; 349 \mathrm{mg} / \mathrm{L}$ dan $350 \mathrm{mg} / \mathrm{L}$. hasil tersebut masih memenuhi baku mutu air minum yaitu $1.000 \mathrm{mg} / \mathrm{L}$. Senada dengan Jiang (2018) dalam risetnya menemukan bahwa pada kawasan karst di provinsi Guangxi, China ditemukan bahwa rata-rata nilai TDS pada sungai yang ada di daerah tersebut jauh lebih kecil dari nilai baku mutu lingkungan yaitu $232 \mathrm{mg} / \mathrm{l}$. Hal ini bertolak belakang dengan hasil penelitian TDS pada daerah pertambangan dimana nilai TDS dapat 
naik hingga hamper mencapai $60 \%$ dari baku mutu yang ditetapkan (Yang, 2018).

TDS atau biasa disebut dengan jumlah zat padat terlarut merupakan indicator jumlah partikel atau zat, baik organic maupun anorganik yang memiliki ukuran di bawah 1 nanometer. TDS dalam air tanah bisa diakibatkan oleh mineral atau zat yang terbawa oleh air. Akan tetapi karena ketika air masuk ke dalam tanah, air akan melewati butiran-butiran tanah yang berpori sehingga pengotor akan terfilter secara alamiah. Oleh karena itu TDS dalam tanah biasanya kecil.

Keberadaan tambang pada kawasan karst seperti karst Tuban wajib diwaspadai, karena secara tidak langsung dapat meningkatkan nilai TDS yang berarti akan menurunkan kualitas air karena melewati baku mutu yang telah ditetapkan.

\section{Parameter Kimia}

\section{(Kadar Oksigen Terlarut)}

Oksigen terlarut dalam air berpengaruh pada keberlangsungan hidup organisme dalam air. Oksigen terlarut di habitat perairan merupakan persyaratan penting untuk bertahan hidup. Persyaratan rata-rata untuk oksigen terlarut oleh ostracodes berada dalam margin yang sangat sempit 7,3-9,5 mg / L.

Parameter kimia yang diukur adalah kadar oksigen terlarut yang diukur menggunakan alat DO meter. Pengukuran dilakukan langsung di lapangan dengan hasil pengukuran disajikan pada Tabel 5 .

Berdasarkan Tabel 5 dapat dilihat bahwa nilai rata-rata kadar oksigen terlarut (DO) pada masing-masing tiitk sampling adalah 2,1 $\mathrm{mg} / \mathrm{L} ; 1,9 \mathrm{mg} / \mathrm{L} ; 1,3 \mathrm{mg} / \mathrm{L}$; dan 1,3 mg/L. nilai ini berada di bawah nilai DO normal berdasarkan Peraturan Pemerintah Nomor 82 Tahun 2001 Tanggal 14 Desember 2001 tentang Pengelolaan Kualitas Air dan Pengendalian Pencemaran Air.

Nilai DO untuk kuaitas air kelas I dan II untuk standar air minum dan air bersih adalah 4-6 mg/L. air bawah tanah cenderung memiliki koandungan oksigen terlarut yang rendah dikarenakan kontak dengan udara yang minim, serta pergerakan air yang terbatas. Selain itu, fitoplankton dalam sungai bawah tanah terbatas karena akses sinar matahari sangat kecil bahkan tidak ada sama sekali pada zona gelap.
Tabel 5. KadarOksigen TerlarutAir Bawah Tanah

\begin{tabular}{lllll}
\multicolumn{5}{c}{ Gua Ngerong } \\
& \multicolumn{4}{c}{$\begin{array}{c}\text { Kadar Oksigen Terlarut } \\
\text { (mg/L) }\end{array}$} \\
\cline { 2 - 5 } & $\mathbf{G 1}$ & $\mathbf{G 2}$ & $\mathbf{G 3}$ & $\mathbf{G 4}$ \\
\hline Sampel 1 & 2,5 & 1,5 & 1,4 & 1,4 \\
\hline Sampel 2 & 2,1 & 1,4 & 1,4 & 1,2 \\
\hline Sampel 3 & 1,7 & 2,9 & 1,2 & 1,2 \\
\hline Rata-rata & 2,1 & 1,9 & 1,3 & 1,3 \\
\hline (Sumber: Hasil Analisis, 2019) \\
(Sumpel
\end{tabular}

Tidak adanya proses fotosintesis mengakibatkan minimnya oksigen yang terlarut dalam air. Kadar oksigen terlarut dalam air sebagian tergantung pada aktivitas kimia, fisik, dan biokimia yang terjadi di dalam air. Oksigen memiliki kelarutan terbatas dalam air yang berhubungan langsung dengan tekanan atmosfer dan berbanding terbalik dengan suhu air dan salinitas.

Tingkat oksigen terlarut rendah dapat membatasi metabolisme bakteri dari senyawa organik tertentu. Dengan menggunakan model regresi (Mahler, 2013) membuat hipotesis bahwa rendahnya nilai DO pada system sungai bawah tanah lebih diakibatkan karena rendahnya debit atau tingginya penarikan air tanah serta peningkatan suhu air tanah sebagai akibat dari perubahan iklim.

Kadar oksigen yang terlarut dalam suatu badan air dinyatakan sebagai oksigen terlarut (DO) yang dinyatakan dengan satuan mg/L. oksigen sangat penting fungsinya untuk proses metabolisme biota air (Suryani, 2013). berdasarkan penelitiannya pada ekosistem perairan pantai, tidak ditemukan perbedaan yang berarti antara ekosistem terumbu karang alami dengan terumbu karang buatan, dimana ekosistem alami memiliki kadar DO sebesar 7,01 mg/L dan ekosistem terumbu karang buatan memiliki nilaiDO 7,31 mg/L.

\section{pH}

Parameter kimia yang diukur selanjutnya adalah $\mathrm{pH}$ menggunakan $\mathrm{pH}$ meter. Pengukuran dilakukan langsung di lapangan di luar goa dengan hasil pengukuran disajikan pada Tabel 6.

Tabel 6. pH Air Sungai Bawah Tanah Gua Ngerong

\begin{tabular}{lcccc}
\hline \multirow{2}{*}{ No sampel } & \multicolumn{4}{c}{ pH } \\
\cline { 2 - 5 } & G1 & G2 & G3 & G4 \\
\hline Sampel 1 & 7,1 & 7,1 & 7,1 & 7,1 \\
\hline Sampel 2 & 7,0 & 7,0 & 7,1 & 7,0 \\
\hline
\end{tabular}




\begin{tabular}{lcccc}
\hline \multirow{2}{*}{ No sampel } & \multicolumn{5}{c}{ pH } \\
\cline { 2 - 5 } & G1 & G2 & G3 & G4 \\
\hline Sampel 3 & 6,9 & 7,1 & 7,0 & 7,1 \\
\hline Rata-rata & 7,0 & 7,1 & 7,1 & 7,1 \\
\hline
\end{tabular}

(Sumber: Hasil Analisis, 2019)

Berdasarkan Tabel 6, dapat diketahui bahwa nilai rata-rata $\mathrm{pH}$ pada masing-masing titik pengambilan sampel adalah 7,0; 7,1; 7,1; dan 7,1. Hasil tersebut memenuhi baku mutu lingkungan hidup pengelolaan kualitas air yaitu 6-9.

Derajat keasaman digunakan untuk menentukan sifat asam dan basa suatu zat atau larutan. Perubahan $\mathrm{pH}$ di suatu badan air sangat berpengaruh terhadap proses reaksi fisika-kimia maupun biologi dari berbagai organisme yang hidup didalamnya. Derajat keasaman juga berpengaruh terhadap daya racun bahan pencemar serta kelarutan beberapa gas dalam pembentukan zat didalam air tersebut. Nilai $\mathrm{pH}$ air digunakan untuk menggambarkan kondisi keasaman atau konsentrasi ion hidrogen dalam air. Skala $\mathrm{pH}$ berkisar antara 1-14. Kisaran nilai $\mathrm{pH}$ 1-7 termasuk kondisi asam sedangkan $\mathrm{pH}$ 7-14 termasuk kondisi basa, sedangkan $\mathrm{pH} 7$ merupakan kondisi netral (Ningrum, 2018).

Dari rata-rata nilai $\mathrm{pH}$ yang diperoleh dari hasil pengukuran sampel air dalam tanah Goa Ngerong dapat diambil kesimpulan bahwa air dalam tanah Goa Ngerong telah memenuhi baku mutu air untuk keperluan hygiene sanitasi dengan nilai pH 7,1 yaitu tidak melebihi maupun kurang dari baku mutu yang telah ditetapkan yaitu 6,5-8,5 dalam Peraturan Menteri Lingkungan Kesehatan Nomor 32 Tahun 2017 tentang Parameter Kimia Kualitas Air untuk Keperluan Hygiene Sanitasi.

Berdasarkan Tabel 6 diketahui tingkat Suhu pada seluruh stasiun $26,4-27,5^{\circ} \mathrm{C}$,. Nilai derajat keasaman $(\mathrm{pH})$ di seluruh stasiun berkisar antara 6,9-7,1. Kecerahan dan pencahayaan merupakan faktor utama bagi kehidupan plankton, khususnya adalah fitoplankton karena berpengaruh pada proses fotosintesis plankton (Hardiyanto, et al., 2012).

Derajat keasaman (pH) juga dapat berpengaruh pada proses laju fotosintesis, $\mathrm{pH}$ optimal bagi plankton berkisar antara 6-9 (Hardiyanto, et al., 2012). Penelitian yang lain pada sistem sungai bawah tanah Goa temu Giring, nilai indikator pH berkisar antara 7,5-8 sehingga masih dapat mendukung pertumbuhan plankton.
Secara umum kondisi kualitas air dalam sistem sungai bawah tanah juga fluktuatif seperti pada badan air permukaan tanah. Hal itu terkait dengan perubahan cuaca, curah hujan, dan sebagainya. Berdasarkan penelitian dari Musgrove (2019) pada akuifer karst di Texas, Amerika Serikat, diperlukan setidaknya 6 series data tiap tahunnya agar didapatkan hasil yang kuat terkait dengan kualitas air di dalam sistem sungai bawah tanah kawasan karst. Data tersebut antara lain adalah suhu, $\mathrm{pH}$, konduktansi spesifik dan oksigen terlarut.

\section{KESIMPULAN}

Dari hasil penelitian dan hasil uji laboratorium didapatkan bahwa sebagian besar sampel penelitian suhu, kekeruhan, TDS, dan pH masih memenuhi baku mutu lingkungan hidup berdasarkan Peraturan Menteri Kesehatan No. 416 Tahun 1990, kualitas air harus memenuhi syarat kesehatan. Sedangkan kualitas DO terlalu rendah, sehingga tidak memenuhi baku mutu.

\section{ACKNOWLEDGEMENT}

Penelitian ini didanai oleh Lembaga Penelitian dan Pengabdian Masyarakat Universitas Islam Negeri Sunan Ampel Surabaya.

\section{DAFTAR PUSTAKA}

Alihar, F. (2018). Penduduk dan Akses Air Bersih di Kota Semarang. Jurnal Kependudukan Indonesia, No.1 Vol. 13. (67-76).

Adji, CN. dan E. Haryono. 2004. Pengantar Geomorfologi dan Hidrologi Karst. Fakultas Geografi UGM, Yogyakarta.

Halim, F., Kawet, L., \& Jasin, M. (2014). Alternatif Pengembangan Sistem Penyediaan Air Bersih untuk Zona Pelayanan IPA SEA Kota Manado. Jurnal Sipil Statik, No. 2 Vol. 2 (107-114).

Hardiyanto, R., Suherman, H. \& Pratama, R. I., 2012. Kajian Produktivitas Primer Fitoplankton di Waduk Saguling, Desa Bongas dalam Kaitannya dengan Kegiatan Perikanan. Jurnal Perikanan dan Kelautan, Vol, 3. No, 4. Hal. 51-59 
Jeannin, P.-Y., Hessenauer, M., Malard, A., \& Chapuis, V. (2016). Impact of global change on karst groundwater mineralization in the Jura Mountains. Science of The Total Environment, 541, 1208-1221.

Jiang, H., Liu, W., Zhao, T., Sun, H., \& Xu, Z. (2018). Water geochemistry of rivers draining karst-dominated regions, Guangxi province, South China: Implications for chemical weathering and role of sulfuric acid. Journal of Asian Earth Sciences, 163, 152-162.

Kementrian Lingkungan Hidup dan Kehutanan Republik Indonesia. (2018). Indeks Kualitas Lingkungan Hidup Indonesia 2017. Jakarta: Kementrian Lingkungan Hidup dan Kehutanan.

Kimprasil. (2002). Pedoman/Petunjuk Teknik dan Manual Bagian 6: Air Minum Perkotaan. Direktorat Jendral Ciptakarya.

Mahler, B. J., \& Bourgeais, R. (2013). Dissolved oxygen fluctuations in karst spring flow and implications for endemic species: Barton Springs, Edwards aquifer, Texas, USA. Journal of Hydrology, 505, 291298.

Massei, N., Dupont, J. P., Mahler, B. J., Laignel, B., Fournier, M., Valdes, D., \& Ogier, S. (2006). Investigating transport properties and turbidity dynamics of a karst aquifer using correlation, spectral, and wavelet analyses. Journal of Hydrology, 329(1-2), 244-257.

Musgrove, M., Solder, J.E., Opsahl, S.P., Wilson, J.T., 2019. Data for timescales of water-quality change in a karst aquifer, southcentral Texas. U.S. Geological Survey data release.

Menteri Kesehatan Republik Indonesia. 1990. Peraturan Menteri Kesehatan Nomor
416 Tahun 1990 Tentang Syaratsyarat dan Pengawasan Kualitas Air.

Ningrum, S. O. (2018). Analisis Kualitas Badan Air dan Kualitas Air Sumur di Sekitar Pabrik Gula Rejo agung Baru Kota Madiun. Jurnal Kesehatan Lingkungan, No.1 Vol. 10 (1-12).

Prakarsa, TBP. 2013. Diversitas, Karakteristik Habitat Roosting, dan Analisis, Mangsa Alami Kelelawar Subordo Microchiroptera Penghuni Gua di Kawasan Karst Tuban dan Karst Menoreh. Tesis. Fakultas Biologi, Universitas Gadjah Mada, Yogyakarta.

Priyowinata, A. 2010. Pemanfaatan Sungai Bawah Tanah untuk Pembangkit Listrik Tenaga Mikro Hidro (PLTMH) $20 \mathrm{~kW}$ di Gua Ngerong, Desa Rengel, Tuban. Tugas Akhir, Juruan Teknik Elektro, Institut Teknologi Sepuluh Nopember.

Said, N.I. (1999). Kesehatan Masyarakat dan Teknologi Peningkatan Kualitas Air. Jakarta: Badan Pengkajian dan Penerapan Teknologi.

Sapparudin. (2010). Pemanfaatan Air Tanah Dangkal sebagai Sumber Air Bersih di Kampus Bumi Bahari Palu. Jurnal SMARTek, No. 2 Vol. 8 (143-152).

Suryani, E. 2013. Keanekaragaman Zooplankton di Perairan Pantai Lekok Kabupaten Pasuruan. Sripsi. Fakultas Sains dan Teknologi. UIN Maulana Malik Ibrahim. Malang. Hal 75

Susanti, R. (2010). Pemetaan Persoalan Sistem penyediaaan Air Bersih untuk Meningkatkan Kualitas Sistem Penyediaan Air Bersih di Kota Sawahlunto. Jurnal Perencanaan Wilayah dan Kota , No. 2 Vol. 21 (111-128)

Wardhana, I. W., Budihardjo, M. A., \& Adhesti, S. (2013). Kajian Sistem Penyediaan Air Bersih Sub 
Sistem Bribin Kabupaten Gunungkidul. Jurnal Presipitasi: Media Komunikasi dan Pengembangan Teknik Lingkungan, 10(1), 18-29. doi: 10.14710/presipitasi.v10i1.1829

Yang, Y., Guo, T., \& Jiao, W. (2018). Destruction processes of mining on water environment in the mining area combining isotopic and hydrochemical tracer. Environmental Pollution, 237, 356-365.

Yassin, M. O., Kawet, L., Halim, F., \& Jasin, M. (2013). Pengembangan Sistem Penyediaan Air Bersih untuk Zona Pelayanan IPA Pilolodaa Kota Gorontalo. Jurnal Sipil Statik , No. 12 Vol. 1 (801806) 